\title{
Pegging Out: Lessons from the Czech Exchange Rate Crisis $^{1}$
}

\author{
David Begg \\ Birkbeck College \& CEPR, 7 Gresse Street, London W1P 2LL, United Kingdom
}

Received June 15, 1998; revised September 3, 1998

\begin{abstract}
Begg, David-Pegging Out: Lessons from the Czech Exchange Rate Crisis
In May 1997 the Czech Republic abandoned its exchange rate peg, the centerpiece of macroeconomic strategy since 1991. This paper examines the usefulness of theories of speculative attack in interpreting the crisis. Significantly, after the crisis subsided, competitiveness returned to its earlier level. One interpretation is that the koruna was the innocent victim of turmoil in Asia. This neglects the trend deterioration of competitiveness prior to the crisis. Hence, the crisis provoked a much-needed adjustment in fiscal policy, which altered the monetary-fiscal mix and consequent equilibrium exchange rate. Sterilization during 1994-96 delayed adjustment. Earlier abandonment of the parity would have helped only if it had also induced the required fiscal adjustment. J. Comp. Econom., December 1998, 26(4), pp. 669-690. Birkbeck College \& CEPR, 7 Gresse Street, London W1P 2LL, United Kingdom. () 1998 Academic Press
\end{abstract}

Journal of Economic Literature Classification Numbers: E58, E65, F31.

\section{INTRODUCTION}

On May 26, 1997, the Czech Republic was forced to abandon finally the fixed exchange rate parity that had been pegged, essentially unaltered, since the outset of reform at the start of 1991. The parity had been defended with determination, despite much conflicting advice during the previous two years. Such advice included: exchange rate appreciation to stave off large capital inflows, exchange rate depreciation to address the ballooning current account deficit, extensive sterilized intervention to insulate the money supply from capital inflows, avoidance of sterilization because of its fiscal costs and increasing ineffectiveness, higher reserve requirements to prevent undue monetary expansion, avoidance of

${ }^{1}$ I thank Mark Allen, Andrew Burns, Biswajit Banerjee, John Bonin, Josef Brada, Oldrich Dedek, Vladimir Dlouhy, Miroslav Hrncir, Laszlo Halpern, Jan Klacek, Judit Nemenyi, Richard Portes, and Charles Wyplosz for helpful comments. Mistakes are my own. 
TABLE 1

Czech Economic Indicators 1991-96, End Year

\begin{tabular}{lrrrrrr}
\hline & 1991 & 1992 & 1993 & 1994 & 1995 & 1996 \\
\hline Inflation (\%) & 52 & 13 & 18 & 10 & 8 & 9 \\
Real GDP growth (\%) & -12 & -4 & -1 & 3 & 6 & 4 \\
Current account/GDP (\%) & & & 0 & 0 & -3 & -8 \\
Budget surplus/GDP (\%) & & & 0 & 1 & 1 & 0 \\
Unemployment (\%) & 28 & 29 & 30 & 28 & 27 & 3 \\
Nominal exchange (koruny/\$) & & 100 & 118 & 122 & 125 & 133 \\
Real effective exchange rate index & & & & 3 & 3 \\
\hline
\end{tabular}

Sources. EBRD (1996) and data supplied to author by Czech National Bank.

Notes. Data before 1993 refer to the Czech component of Czechoslovakia. Exchange rates (at end year) fluctuate against the dollar since 1993 because of (a) adoption of peg against a basket (DM \& $\$$ ), and (b) introduction of wider bands in 1996. REER is based on relative producer prices.

such additional burdens on banks until they were in sounder health, fiscal contraction to reduce overheating, fiscal expansion to counter the economic slowdown caused by export stagnation, monetary tightening to curb import demand, and monetary relaxation to ease interest rates and allow some exchange rate depreciation. Nor were disagreements entirely ex ante. Since the crisis, there have been a variety of ex post rationalizations for what took place including: the economy overheated, foreign lenders lost their nerve, corporate control was exposed as inadequate, mistakes in monetary and fiscal policy were made.

This paper examines the Czech experience in order to understand, and arbitrate between, these competing claims. The episode, and the policy dilemmas it reveals, are, of course, of wider significance, and the paper aims to draw wider lessons for policy design. Section 2 provides a brief history of the Czech economy. Section 3 draws on the theoretical literature on speculative attacks to ask for which clues we should be looking. Section 4 evaluates competing accounts of what occurred and discusses whether other policies would have made a difference. Section 5 gauges early evidence on how hard a landing the Czech economy then made. Section 6 draws more general lessons.

\section{THE EVOLUTION OF THE CZECH ECONOMY}

Table 1 provides key macroeconomic data on the Czech economy during 1991-96. The Czechs and Slovaks were divorced in 1993, although inflation and output estimates are available for the Czech part of the CSFR in 1991-92. Table 1 records rapid disinflation to below $10 \%$ a year, the resumption of moderate growth after 1993, a current account deficit that spiraled to 8\% of GDP by 1996 financed essentially by capital inflows, a central government budget close to balance, and persistently low unemployment. 
The exchange rate was pegged in January 1991 at 28 koruny/dollar, with a narrow band of plus or minus 0.5\%. In May 1993 the peg was redefined against a basket of $65 \% \mathrm{DM}$ and $35 \%$ US \$, but the narrow band was maintained. In February 1996, the band was widened to plus or minus 7.5\%, although the central parity was maintained. Finally, in May 1997 speculative pressure forced abandonment of the peg in favor of a managed float. The exchange rate depreciated initially to $10 \%$ below the original parity, before making a partial recovery.

Three aspects of microeconomic reform should be emphasized. First, the task for structural adjustment was enormous. The CSFR had been 97\% state owned prior to reform. Second, mass privatization through vouchers was pursued vigorously in the Czech Republic. Privatization funds enabled some diversification of risk, but ownership of these funds was quickly concentrated in banks, some of the largest of which still were state owned. Third, as in other transition economies, the solvency of banks was precarious and early emphasis on financial regulation insufficient.

\section{THEORIES OF SPECULATIVE ATTACK}

A speculative attack is a discrete change in private sector behavior on financial markets in anticipation of a change in the policy regime. The change may be reflected in asset quantities or asset prices, although in the latter instance something stochastic is required to explain why excess profit opportunities were not foreseen by the market. Models of speculative attack fall essentially into three types. The family of models sired by Krugman (1979) assumes an initial policy regime that is not sustainable forever. Exogenous trend deterioration of the fundamentals leads to a speculative attack, accompanied by a change of regime, namely reversion to floating, as soon as it can succeed. Being foreseeable, the attack is reflected in reserves but not interest rates or the exchange rate. Making trend deterioration in fundamentals stochastic rather than deterministic allows some discrete exchange rate depreciation in the crisis and, therefore, introduces a risk premium into interest rates prior to this date.

Such insights can be recast within a target zone, most interestingly within a one-sided target zone (Krugman and Rotemberg, 1992) with a firm commitment only to prevent undue depreciation. Even if fundamentals follow a trendless random walk, their intermittent triggering of defense of the band against depreciation will on average provide a reserve drain. Once reserves fall below some critical level, a speculative attack becomes possible. Elimination of foreseeable profits again implies that the attack occurs as soon as it will first succeed. This family of discrete change in regime models fails to explain why policymakers choose optimally this sequence of regimes, not least because all available reserves are pledged solely to support of the first regime (Obstfeld and Rogoff, 1996). 
Regimes with multiple equilibria (Obstfeld, 1995, 1996) offer an alternative rationale, balancing the reputational costs of changing the regime against costs to the real economy of maintaining an inappropriate nominal exchange rate. Because private expectations affect the nominal variables that policymakers must decide whether or not to accommodate, self-fulfilling expectations can validate different equilibria. Crisis may then reflect changes in regime fueled by changes in expectations rather than by changes in observable fundamentals.

This is not to say that fundamentals are irrelevant. Even fundamentals are endogenous once we model policy selection. The structural parameters that govern the evolution of policy variables also determine the ranges in which multiple equilibria are feasible. Economies exhibiting strong fundamentals are innately less prone to speculative attacks whose function is to shift the economy from one feasible equilibrium to another (Jeanne, 1995; Obstfeld, 1996; Velasco, 1997). Obstfeld and Rogoff (1996) argued the pervasive failure of interest rates to anticipate attacks before they come over the horizon suggests attacks are rarely associated with evident trend deterioration of fundamentals; moves between multiple equilibria may be an alternative rationalization.

A third, possibly related, interpretation of attacks is that they reflect contagion, the triggering of sequential crises across countries. This may be viewed as a sunspot mechanism, of no innate fundamental significance but nevertheless a coordination device for expectations of market participants, thereby facilitating a self-fulfilling shift in expectations and equilibrium. As an information cascade, it is the final revelation of cumulated inside information, for example a reassessment of the degree of capital mobility. As sequential spillovers, each depreciation affects the equilibrium exchange rate for the next country. Whatever the theoretical arguments about contagion, there is powerful empirical evidence (Eichengreen et al., 1996) that exchange rate crises in different countries are closely clustered in time.

Formal models of crises give us indications of what evidence to seek, but they are not the whole story. Tractable models so streamline the specification, both of policy and of private behavior, that they provide at best stylized accounts of what might take place. The ensuing discussion of the Czech Republic, therefore, pays additional attention both to the dilemmas of policy design and to the context of an economy in transition.

\section{COMPETING DIAGNOSES OF CAUSES OF THE CRISIS}

Models of speculative attack are driven by two different types of fundamentals: solvency and competitiveness. The latter of course presupposes some nominal inertia, but that is a reasonable assumption in Europe even in transition economies (Pujol and Griffiths, 1996; Cottarelli and Szapary, 1998). Take competitiveness first. 
TABLE 2

The Real Exchange Rate and Indicators of Competitiveness

\begin{tabular}{|c|c|c|c|c|c|c|c|c|}
\hline Czech Republic & 92 & 93 & 94 & 95 & 96 & $97 \mathrm{i}$ & 97ii & 97 June \\
\hline $\begin{array}{l}\text { Real effective exchange rate: } \\
\text { (relative producer prices) }\end{array}$ & 100 & 118 & 122 & 125 & 133 & 142 & 134 & 129 \\
\hline \multicolumn{9}{|l|}{ Memo items } \\
\hline Consumer price index & 100 & 121 & 133 & 145 & 157 & 164 & 166 & 167 \\
\hline Producer price index & 100 & 113 & 119 & 128 & 134 & 138 & 139 & 139 \\
\hline \multicolumn{9}{|l|}{ Industrial productivity } \\
\hline Large firms & 100 & 101 & 108 & 118 & 131 & & & \\
\hline Also including smaller firms & 100 & 99 & 104 & 115 & 125 & & & \\
\hline Annual \% real GDPgrowth & -4 & -1 & 3 & 6 & 4 & 2 & 1 & \\
\hline \multicolumn{9}{|l|}{ Goods \& services ( $\%$ of GDP) } \\
\hline Exports & & 57 & 52 & 59 & 58 & & & \\
\hline Imports & & 55 & 56 & 64 & 66 & & & \\
\hline Trade balance & & 2 & -4 & -5 & -8 & & & \\
\hline \multicolumn{9}{|l|}{$\begin{array}{c}\% \text { annual increase in unit labor } \\
\text { costs (business sector) }\end{array}$} \\
\hline Czech Republic & & & 17 & 17 & 12 & & & \\
\hline Germany & & & 0 & -2 & 0 & & & \\
\hline Austria & & & 0 & 2 & 1 & & & \\
\hline USA & & & 2 & 3 & 3 & & & \\
\hline
\end{tabular}

Sources. OECD (1997), IMF (1997) and data supplied to author by Czech National Bank.

\subsection{Pegged Exchange Rate, Continuing Inflation: Had the Exchange Rate Simply Become Overvalued?}

The original parity, adopted in January 1991, had involved a substantial depreciation and was intended to ensure that the economy was highly competitive initially. Despite dramatic disinflation after initial price liberalization, Table 1 confirms that the Czech Republic continued to experience annual inflation around $10 \%$, well in excess of that experienced by its Western trading partners. Had the Czech exchange rate simply become overvalued? Any assessment must rest on two judgments, the initial level of competitiveness and subsequent changes in that position. The latter calculation is shown in Table 2.

Line 1 of Table 2 reports the real exchange rate, calculated from the evolution of the nominal effective (trade weighted) exchange rate and producer prices in the relevant countries. Czech inflation, coupled with a fixed nominal exchange rate, induced a real appreciation of $40 \%$ between 1992 and the first quarter of 1997. However, Halpern and Wyplosz (1997) showed that real appreciation is a trend phenomenon pervasive in transition economies, consistent with the Balassa-Samuelson view that rapid productivity growth in traded goods allows appreciation of the equilibrium real exchange rate. Table 2 confirms that during 
1994-96 industrial productivity was growing quite rapidly, certainly more rapidly than in the Czech Republic's main trading partners.

Two considerations suggest that productivity growth was probably insufficient to prevent an erosion of competitiveness and hence of profits from exporting. First, OECD (1997) contains direct estimates of nominal unit labor costs. These are shown at the bottom of Table 2. Whereas in competitor countries wage growth scarcely exceeded productivity growth, in the Czech Republic wage growth was substantially above increases in industrial productivity, leading to double-digit increases in nominal unit labor costs. Unless the traded goods sector was wildly different from these estimates of the whole business sector, the conclusion must be that rapid wage growth undermined competitiveness despite modest increases in productivity. ${ }^{2}$

Second, we can look at trade performance directly. Table 2 shows that, by 1996, exports were scarcely a larger share of GDP than in 1993. Export growth, which in 1994-95 had finally attained respectable rates, began to fall back in 1996. However, export growth was still positive (OECD, 1997, estimates 5.3\% for real export growth in 1996). Table 2 makes clear that the big external story was the dramatic and sustained rise in imports. Since there was no equivalent collapse in exports, this reminds us that the diagnosis of stagnating competitiveness should not be oversold. ${ }^{3}$

Two further pieces of evidence suggest it is unlikely that competitiveness had fallen much below its equilibrium level. First, sharp export growth had resumed in the second quarter of 1997 before the exchange rate depreciation. Second, this occurred despite the fact that, shortly after the crisis, the real exchange rate was identical to its 1996 value. Table 3 gives brief details. It is possible to get a cross check on these inferences from Tables 2 and 3. Using data from economies other than those in transition, Halpern and Wyplosz (1997) estimated equations relating equilibrium real exchange rates, measured by the dollar value of domestic wages, to easily measurable data that can then be used to deduce the equilibrium path of competitiveness in transition economies. Their estimates for the Czech Republic are reproduced in Fig. 1, which corroborates the diagnosis of the preceding paragraphs. Strong wage growth had been steadily eroding competitiveness, raising the dollar value of domestic wages, but not yet to a level at which dollar wages exceeded their estimated equilibrium path.

Figure 1 suggests that, while the level of competitiveness was still adequate,

${ }^{2}$ Although I have been unable to obtain data distinguishing productivity by sector, Table 2 does report estimates of productivity growth not merely in large firms usually recorded in international statistics but also for a sample containing smaller firms as well. Since some of the largest firms are in nontraded goods such as transport and domestic energy, it is hard to argue that comparison of the two rows of productivity data in Table 2 provides support for the proposition that productivity growth in traded goods was sufficiently fast to prevent all erosion of competitiveness.

${ }^{3}$ Moreover, as we shall shortly see, some of the import surge can be associated with imports of capital goods likely to enhance productivity and competitiveness at some future date. 
TABLE 3

External Trade and the Real Exchange Rate

\begin{tabular}{lrrrrrrr}
\hline & 1996 & $96 \mathrm{i}$ & $96 \mathrm{ii}$ & $96 \mathrm{iii}$ & $96 \mathrm{iv}$ & $97 \mathrm{i}$ & $97 \mathrm{ii}$ \\
\hline Real exchange rate (producer prices) & 132.4 & & & & 135.6 & 142.0 & 133.7 \\
Real growth (\%, year on year) & & & & & & & \\
$\quad$ Exports of goods \& services & & 5.0 & 2.1 & 3.6 & 2.7 & -0.4 & 15.4 \\
$\quad$ Imports of goods and services & & 11.6 & 7.9 & 18.5 & 9.4 & 6.7 & 10.5 \\
\hline
\end{tabular}

Source. Data supplied to author by Czech National Bank.

its rate of deterioration could not have been sustained indefinitely. Two features of the Czech experience, intelligent anticipation of future problems with fundamentals and a relatively soft landing for the real exchange rate after the crisis, have attributes of the classic balance of payments crisis (Krugman, 1979). However, in key aspects the crisis did not conform to this stereotype.

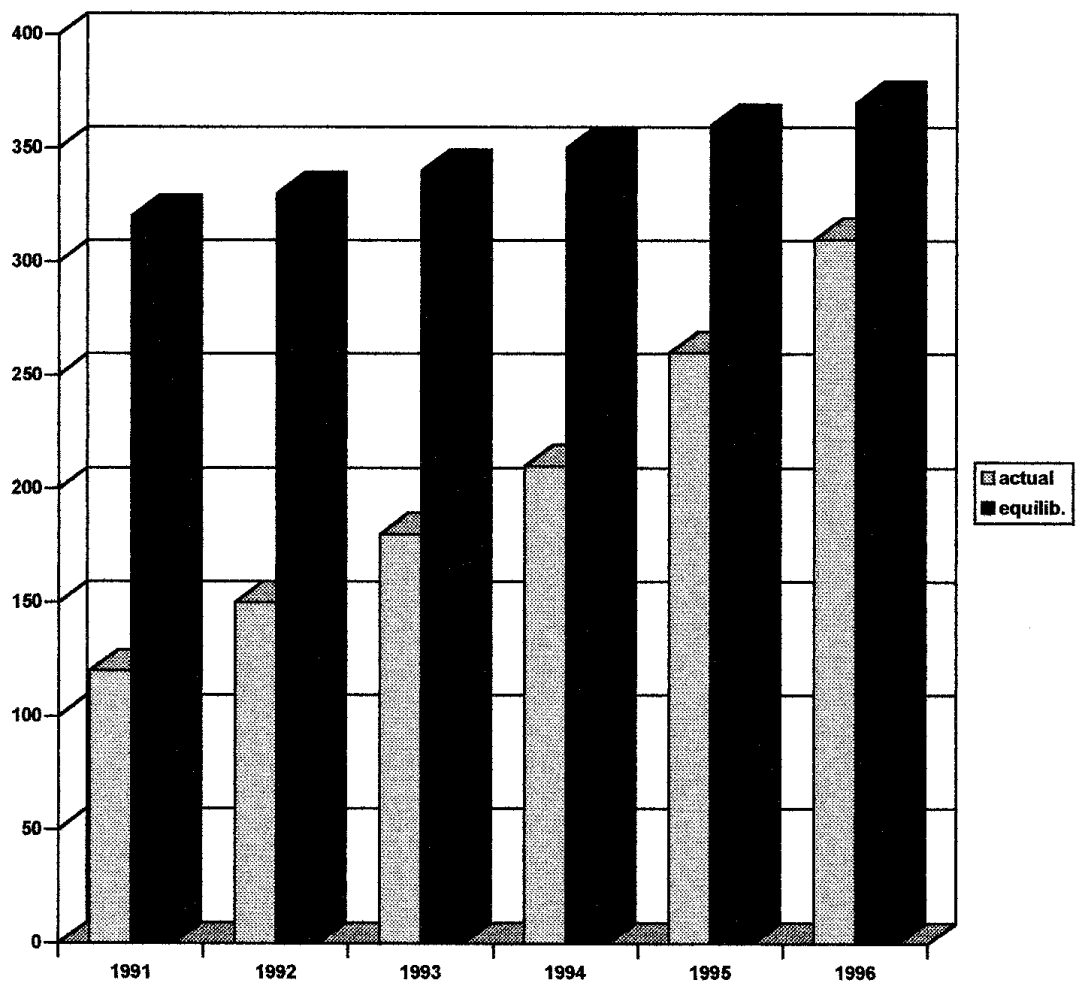

FIG. 1. Index of actual and equilibrium Czech exchange rates 1991-96 (monthly wages in US \$, actual and estimated equilibrium level). Source: Halpern and Wyplosz (1997). 
TABLE 4

Official Foreign Currency Reserves

\begin{tabular}{lllccccc}
\hline & 1993 & 1994 & 1995 & 1996 & $97 \mathrm{i}$ & $97 \mathrm{ii}$ & 97 July \\
\hline Reserves (US \$ bn) & 3.8 & 6.2 & 13.9 & 12.4 & 11.6 & 10.7 & 10.8 \\
Reserves/imports & 0.29 & 0.41 & 0.55 & 0.45 & 0.38 & 0.41 & 0.41 \\
\hline
\end{tabular}

Source. IMF (1997).

Note. Second row denotes stock of reserves divided by annualized flow of merchandise imports.

First, as Table 1 reveals, the measured budget deficit of central government essentially was in balance. Core inflation in the Czech Republic was less a need for inflation tax revenue than the consequence of the following: inflation inertia, protracted structural adjustment and only gradual elimination of price controls for household heating and rents; weak corporate control and wage discipline; and remarkably low levels of unemployment. Some of these difficulties are slowly being overcome, allowing the prospect of some future disinflation, unlike in the Krugman model, which posits perpetual inflation after the crisis occurs. This may also help explain the softer landing, in particular with respect to reserve depletion.

\subsection{Deteriorating Solvency and Steady Reserve Depletion}

Not only did the Czech experience fail to exhibit the fiscal fundamentals required for a Krugman crisis, but it only partly exhibited the key symptom: steadily diminishing reserves before the event and a discrete collapse of reserves during the crisis. Table 4 shows the evolution of official reserves of foreign currency, which increased steadily until early 1996, then began to fall, especially in 1997. It was indeed a crisis, but not to the extent implied by a conventional crisis model.

The massive capital inflows of 1994-96 allowed reserves to build up despite the current account deficits recorded in Table 1. The eventual balance of payments crisis reflected a switch from capital inflows to incipient outflows. There are several possible explanations that should be examined more closely: a waning commitment to structural adjustment and the consequent crisis of confidence of foreign investors, leading to a reversal of foreign direct investment (FDI); a change in the configuration of interest differentials and likely exchange rate changes, inducing an outflow of hot money; and the cumulative effect of the previous response to monetary inflows, a vast program of sterilized intervention that delayed rather than promoted necessary macroeconomic adjustment.

Table 5 shows balance of payments flows during 1993-96, giving details of the capital flows that financed current account deficits. Inflows peaked during 1995 when capital inflows reached a massive $17.4 \%$ of GDP. The payments deficit in 
TABLE 5

Capital Flows 1993-96 (\% of GDP)

\begin{tabular}{lcccc}
\hline & 93 & 94 & 95 & 96 \\
\hline Balance of payments surplus & 9.8 & 9.7 & 15.8 & -1.5 \\
Current account & 2.2 & -0.2 & -2.9 & -8.2 \\
Errors and omissions & -0.3 & -2.6 & 1.3 & -0.7 \\
Capital account & 7.9 & 12.5 & 17.4 & 7.4 \\
Capital transfers & -1.8 & 0 & 0 & 0 \\
Net FDI & 1.8 & 2.1 & 5.4 & 2.5 \\
Net portfolio investment & 5.1 & 2.3 & 2.9 & 1.3 \\
Other capital flows & 2.8 & 8.1 & 9.1 & 3.6 \\
Mon. authorities & 0.3 & -0.1 & 0.1 & 0 \\
General govt. & 0 & 1.3 & -1.0 & 0 \\
Banks & 0.1 & 2.0 & 6.5 & 0.7 \\
Other & 2.4 & 4.9 & 3.5 & 2.9 \\
\hline
\end{tabular}

Source. IMF (1997), data supplied by the Czech National Bank, and author's calculations.

1996 took place despite continuing capital inflows of 7.4\% of GDP. Decomposing capital flows into their components shed light on whether inflows were primarily direct and portfolio investment associated with privatization or primarily other capital flows, such as hot money and medium-term borrowing by residents, reflecting either perceived deviations from uncovered interest parity or simply domestic capital market imperfections. ${ }^{4}$

Together, FDI and net portfolio inflows amounted to 4.4\% of GDP in 1994 and $8.3 \%$ in 1995 when the telecommunications sector was privatized, but only $3.8 \%$ in 1996 when the pace of privatization slowed. With the commitment to further privatization waning, investors may have expected structural capital inflows to be more modest in the future..$^{5}$ Deprived of this source of payments financing, adjustment in the current account suddenly became a critical issue. To the extent that this interpretation is correct, it draws attention to two issues: the importance of domestic politics and the question of whether retaining the exchange rate peg too long scared off FDI inflows that otherwise might have been enjoyed for longer.

Interestingly, Table 5 does not support the view that capital inflows were principally related to privatization, either as FDI or via more general portfolio

${ }^{4}$ Begg (1996) reported and discussed the claim that Czech firms and banks borrowed abroad because there were no domestic sources of medium term loans. To the extent that this is correct, it increases the presumption that capital inflows were associated with spending rather than portfolio shifts in accumulated savings and thus were likely to fuel overheating of the Czech economy.

${ }^{5}$ Since privatization of banks had been on the agenda for some time, it is of course difficult to assess after the fact what would have been reasonable expectations to have held at the time. 
investment. Other capital flows, $8 \%$ of GDP in $1994,9.1 \%$ in 1995 , and $3.6 \%$ in 1996, were even more important than direct and portfolio investment in explaining both the flood of capital inflows in 1994-95 and the slowdown thereafter. ${ }^{6}$ While the exchange rate remained credibly pegged within a narrow band, substantial interest differentials encouraged foreign borrowing by Czechs and foreign lending to Czechs.

In February 1996, the narrow exchange rate band was widened, although the parity remained unchanged. One purpose in adopting wider bands was to introduce more short-term uncertainty about the exchange rate, thereby hoping to throw risk into the wheels of capital mobility. Initially, the change in regime appeared highly successful; during the first two quarters of 1996, cumulative inflows under other capital flows were close to zero. The temporary resumption of inflows thereafter does not disprove the usefulness of the wider exchange rate band but rather it was a response to an unhelpful change in the monetary-fiscal mix discussed below.

Table 5 makes another point vividly. The source of these financial inflows was not the government or the monetary authorities; rather it came through banks and other activities of firms and households. In part, this reflected an increase in the demand for domestic money. Although, on average, it was likely to be sustained, and therefore met properly by allowing an increase in money supply, money demand was also potentially volatile. Agents familiar with the use of foreign currency deposits and facing increasing degrees of capital mobility were always likely to consider currency substitution and were capable of temporarily reducing demand for domestic money when the prospect of a crisis threatened higher yields on overseas assets. ${ }^{7}$ To the extent that banks and the public did not intend to use capital inflows to add to money balances, they must have planned to spend them on consumption or physical investment. With the economy operating close to full capacity, such demand had to spill over into imports; hence the dramatic increase in the current account deficit in 1996-97. The key issue was whether or not it was reasonable to have expected such deficits to continue to be financed by capital imports or whether other policy action should have been taken earlier. ${ }^{8}$ One interpretation of the inflow is that the creditworthiness of the Czech Republic had increased permanently; if so, the textbook response is to utilize the additional borrowing to implement some intertemporal smoothing, borrowing against the future success of transition. Imports of investment goods, and even consumer goods, were then the symptom of this increased creditworthiness and

\footnotetext{
${ }^{6}$ Begg (1996), 1998) discussed the extent to which these were motivated by perceived deviations from uncovered interest parity.

${ }^{7}$ For an early examination of money demand not only in the Czech Republic but also in other transition economies, see Begg et al. (1996).

${ }^{8}$ Portes and Vines (1997) stressed that, when capital inflows are sustained for a long time, the fundamental equilibrium exchange rate appreciates for the foreseeable future and the appropriate policy response is to allow the real appreciation to take place.
} 
TABLE 6

GDP and Its Components

\begin{tabular}{|c|c|c|c|c|c|c|c|}
\hline & \multirow[b]{2}{*}{ GDP } & \multicolumn{2}{|c|}{ Consumption } & \multicolumn{2}{|c|}{ Investment } & \multirow[b]{2}{*}{ Exports } & \multirow[b]{2}{*}{ Imports } \\
\hline & & Household & Government & Total & Fixed & & \\
\hline \multicolumn{8}{|c|}{ Real growth (\%) } \\
\hline $1995 \mathrm{i}$ & 5.4 & 4.9 & 2.2 & 35.9 & 21.9 & 18.0 & 28.9 \\
\hline ii & 6.5 & 6.0 & 1.7 & 25.1 & 25.0 & 10.6 & 19.5 \\
\hline iii & 6.3 & 6.1 & -3.3 & 10.4 & 25.0 & 17.6 & 15.4 \\
\hline iv & 5.5 & 7.6 & 1.0 & 18.7 & 18.9 & 16.9 & 24.2 \\
\hline $1996 \mathrm{i}$ & 4.4 & 6.6 & 0.7 & 18.1 & 17.0 & 5.0 & 11.6 \\
\hline ii & 4.0 & 7.2 & 3.7 & 9.8 & 11.1 & 2.1 & 7.9 \\
\hline iii & 3.9 & 6.7 & 2.5 & 28.0 & 6.2 & 3.6 & 18.5 \\
\hline iv & 3.9 & 4.8 & 3.9 & 14.3 & 5.3 & 2.7 & 9.4 \\
\hline $1997 \mathrm{i}$ & 1.5 & 5.2 & 3.6 & 8.7 & 1.8 & -0.4 & 6.7 \\
\hline ii & 1.2 & 5.6 & 1.9 & -10.0 & -4.8 & 15.4 & 10.5 \\
\hline \multicolumn{8}{|c|}{ Share of GDP $(\%)$} \\
\hline 1994 i & & 51 & 24 & 23 & 20 & 56 & 54 \\
\hline $1995 \mathrm{i}$ & & 51 & 23 & 29 & 23 & 61 & 65 \\
\hline $1996 \mathrm{i}$ & & 52 & 22 & 33 & 24 & 60 & 65 \\
\hline $1997 \mathrm{i}$ & & 53 & 20 & 34 & 24 & 55 & 63 \\
\hline
\end{tabular}

Source. Czech Statistical Office data made available to the author via the Czech National Bank.

Notes. Growth measured relative to same quarter in preceding year. Total investment comprises gross fixed investment plus inventory accumulation.

the only noninflationary way to meet the additional demand when the economy was already at full capacity.

However, there are several reasons to question whether it was reasonable for policy to be based on the assumption that inflows would continue not merely at the exceptional levels of 1994-95 but even at the substantial levels of 1993 or 1996. After all, capital inflows sustained at nearly $8 \%$ of GDP would have come close to financing even a current account deficit of $8.2 \%$. First, Fig. 1 indicates that competitiveness was steadily being eroded and would become a problem unless the trend growth of unit labor costs could be curtailed either by faster productivity growth or by slower wage growth. The perception of a weakening of momentum in microeconomic reform made the first unlikely and the fact that the economy was overheating made the second unlikely. Second, to the extent that inflows were tied to privatization directly, a reduced pace of privatization may have reduced inflows directly.

Nevertheless, two factors delayed the crisis by providing more optimism about the long run and some immediate relief in the short run. First, the sheer volume of gross fixed capital formation had increased to over 25\% of GDP (see Table 6), which carried with it the prospect of substantial future increases in productivity. 
However, investment takes time to gestate. ${ }^{9}$ The second question therefore became whether other policies, for example monetary policy and/or exchange rate policy, could provide the requisite incentives to maintain capital inflows until structural investment could yield its fruit.

\subsection{Monetary Policy Issues}

Although the exchange rate peg served Czechoslovakia well, allowing rapid disinflation and visible commitment to stabilization, it is ironic that the same policy created many more problems for the Czech Republic after the separation from Slovakia in 1993. As the Czech Republic, having achieved low inflation and pressing on with mass privatization, became one of the darlings of global investors and international agencies, the capital inflows documented above became massive. In principle, those inflows prompted by higher money demand should have been accompanied by unsterilized intervention. Sachs (1996) argued that one of the principal advantages of an exchange rate peg is that it allows liquification of the economy as confidence increases, without any need for domestic credit creation that might cast doubt on the commitment to future prudence in macroeconomic policy. Conversely, to the extent that global markets took the view that substantial investment in infrastructure and physical capital was enhancing future competitiveness, the appropriate policy response is to allow a real appreciation of the exchange rate (Begg, 1996; Portes and Vines, 1996).

In practice, the authorities embarked on a vast campaign of sterilization, retaining the narrow exchange rate band and neutralizing monetary inflows through sales of domestic instruments. Table 7 draws attention to the extent of sterilization. During 1993-96, the increase in net foreign assets of the monetary authorities exceeded the increase in the monetary base. Net domestic credit creation was minus 190 billion crowns, despite the fact that the narrow monetary base more than doubled. Table 7 records an increase of 139 billion crowns.

Given the extent of capital mobility and some attempts to reimpose capital controls notwithstanding, sterilization was always a dangerous policy (Begg, 1996). It prevented the essential adjustment required, thereby inducing additional and unnecessary monetary inflows that had the potential to become outflows. Nor were the authorities acting without the benefit of experience elsewhere. In addition to examples more remote in time and relevance, the more obvious parallel was with the Mexican crisis of late 1994. Analyses of the Mexican crisis, such as that of Sachs et al. (1996), accord a significant role to the policy of sterilization.

\footnotetext{
${ }^{9}$ Moreover, the failure of high investment under central planning to generate sustained and rapid growth reminds us that market incentives and corporate governance are critical in translating greater availability of capital into larger output from capital. Whether the Czech Republic could make effective use of new investment is to some extent still unproven.
} 
TABLE 7

Balance Sheet of the Monetary Authorities 1993-97 (bn koruny)

\begin{tabular}{lrrrrr}
\hline & 93 & 94 & 95 & 96 & 97 Nov \\
\hline Assets & & & & & \\
$\quad$ Net foreign assets & 17 & 83 & 180 & 364 & 341 \\
$\quad$ Net domestic assets & 99 & 29 & -33 & -170 & -91 \\
$\quad$ Liabilities & & & & 194 & 250 \\
$\quad$ Narrow monetary base & 111 & 112 & 147 & 194 \\
\hline
\end{tabular}

Source. Data supplied to author by the Czech National Bank.

Notes. The above refers to the narrow monetary base. Data in IMF (1997) refer to the wide monetary base, including CNB bills and other deposits with the CNB; on the asset side, net domestic assets are correspondingly higher when such claims are recorded as liabilities rather than deducted from net assets. Despite rapid increases in the narrow monetary base during 1994-97, broad money increased much more slowly (at annual rates of $19.4 \%$ in $1995,7.8 \%$ in $1996,6.3 \%$ in $1997 \mathrm{i}$, and $6 \%$ in 1997ii). The consequent falls in the money multiplier were in part deliberate as the authorities undertook measures, such as higher reserve requirements, to help sterilize monetary inflows.

The avowed purpose of the exchange rate peg was to make disinflation easier in the Czech Republic. The supreme paradox is that by 1995-96 adherence to the peg, by utilization of extensive sterilization, was making disinflation more difficult. Since capital mobility was by no means low, some sterilization was ineffective. ${ }^{10}$ This suggests that monetary growth was, in fact, higher than intended and disinflation slower than projected. Therefore this prolonged disinflation hastened the demise of the peg.

By 1996, with unit labor costs increasing steadily, the current account deficit increasing sharply, and capital inflows starting to abate, it was evident that some policy response was needed. Given the persistent failure of the government to tighten fiscal policy substantially, a symptom of political weakness as well as of inappropriate analysis (see Section 4.4), the Central Bank was forced to act. Table 8 shows the consequent fall in the real stock of broad money (M2) and the accompanying increase in the Prague interbank offer rate. ${ }^{11}$ Real interest rates therefore increased and the real exchange rate appreciated in late 1996 and early 1997.

In February 1996, the exchange rate band had been widened, and during the first two quarters this was successful in introducing additional risk and staving

${ }^{10}$ Contemporaneous estimates of the offset coefficient ranged from one third to two thirds (Begg, 1996).

${ }^{11}$ Increases in PRIBOR exceeded those in officially set interest rates. Although in part this may suggest an increase in equilibrium risk premia, a clue for which some crisis models suggest we should be looking, the increase is also consistent with the use of open market operations to tighten monetary policy deliberately. The wide monetary base fell from 4\% from end 1995 to the first quarter of 1997 despite an increase of $10 \%$ in the price level during the same period (IMF, 1997). 
TABLE 8

Recent Developments in Monetary Policy

\begin{tabular}{lrrrrr}
\hline & 94 & 95 & $96 \mathrm{iv}$ & $97 \mathrm{i}$ & $97 \mathrm{ii}$ \\
\hline Real money growth (\%annual change in M2/CPI) & 10.8 & 10.3 & -1.0 & -0.8 & -0.9 \\
PRIBOR (3 month, \%, at annual rate) & 9.1 & 11.0 & 12.7 & 12.4 & 19.4 \\
CPI inflation (\%, year on year) & 10.0 & 9.1 & 8.6 & 7.2 & 6.6 \\
Implied real interest rate & -0.9 & 1.9 & 4.1 & 5.2 & 12.8 \\
Real effective exchange rate & 122 & 125 & 136 & 142 & 134 \\
$\quad$ (producer prices, 1992 = 100) & & & & & \\
\hline
\end{tabular}

Source. Data supplied to author by Czech National Bank.

off capital inflows. ${ }^{12}$ Subsequent monetary tightening however was a two-edged sword. By reducing aggregate demand, it reduced import demand; however, by raising real interest rates, it provided further capital inflows or, for the first time, the possibility of nominal appreciation within the wider band, thereby reducing competitiveness. In practice, there was some resumption of inward capital flows, as shown by the annual inflow data in Table 5 leading to some real appreciation, as shown in Table 8. The simultaneous impact of the credit squeeze and real appreciation helps explain the significant slowdown of the Czech economy in the first few months of 1997. Although import growth was reduced, exports also fell. Because confidence in the peg, despite a measurable and sustained appreciation in the real exchange rate over several years, required belief in continuing rapid productivity growth in the traded good sectors, any indication of an export slowdown, whatever the causes, ran the risk of jeopardizing optimistic projections about future export growth.

\subsection{There Was, of Course, a Better Way}

So far the problem has been portrayed as increased creditworthiness, reflected in substantial foreign borrowing to finance not merely investment but also consumption and demand that spilled over into substantial imports because the domestic economy was close to full capacity. Because many of the imports of capital goods were for infrastructure projects with long gestation periods, they had yet to have a large effect on productivity and competitiveness. Meanwhile, with competitiveness being eroded and external solvency deteriorating, tightening of monetary policy may have exacerbated the problem by inducing a further real appreciation and calling into question the reliability of projections of sustainable export growth. The visible warning of political commitment to

${ }^{12}$ Leiderman and Bufman (1996) argued that band widening diminished capital mobility in Israel. 
further microeconomic reform further undermined confidence in those projections. $^{13}$

If policymakers wished to retain the exchange rate regime, there seemed to be two simple textbook prescriptions. First, to the extent that the strategy relied on maintaining the confidence of foreign investors until substantial physical investment had time to be reflected in productivity, confidence should not have been jeopardized by allowing the momentum of structural adjustment to diminish substantially. Second, because competitiveness would remain a concern during this interim period, and perhaps longer if the trend in Fig. 1 could not be arrested, fiscal policy had to be tightened. This would have had two distinct functions. First, it would have removed excess aggregate demand and overheating. Second, it would have allowed correction of the fiscal-monetary mix. Failure to tighten fiscal policy by 1996 was a policy error.

Policymakers achieved near budget balance during 1996 and were planning for something similar in 1997. It is an error commonly made, such as in the United Kingdom during 1987-89. When borrowing constraints are relaxed, whether as a result of financial deregulation or increased creditworthiness, a boom in consumption and investment is inevitable and is likely to cause both domestic inflation and current account deficits. With substantial foreign assets and a flexible exchange rate, as in the UK during 1987-89, riding out the external pressure may be possible provided consumers and investors are planning to satisfy their intertemporal budget constraints. All that is required is that this be credible to lenders. Even then, however, it is desirable to prevent substantial domestic overheating. Budget balance may be quite inadequate; a substantial budget surplus may be required temporarily when the private sector is running a large deficit. The famed "Lawson boom" in the United Kingdom took place despite the only two years of budget surpluses in the past three decades.

By 1997 the Czech boom was fading out, but that was principally the result of monetary policy, maintenance of the parity despite continuing inflation and deteriorating competitiveness, and then the additional tightening of monetary policy in 1996 described above. The longer the introduction of tighter fiscal policy was delayed, the more it became likely that fiscal tightening would have to be accompanied by an appropriately looser monetary policy, in other words a change in the monetary-fiscal mix. Tighter fiscal policy, to some extent accompanied by looser monetary policy, would have allowed a much earlier abatement of capital inflows. With lower interest rates, deviations from interest parity would have been less pronounced during 1995-97. This would have had three benefits: a lower fiscal cost of sterilization; less leakage from ineffective sterilization into unnecessary growth of the domestic money supply, thereby reducing the loss of

\footnotetext{
${ }^{13}$ One of the proximate causes of the crisis was the refusal of the government in April 1997 to approve further microeconomic reforms seen as desirable by international agencies and considered by the Czech National Bank to be necessary for underpinning the existing macroeconomic strategy.
} 
competitiveness implied at the fixed nominal parity or, alternatively, a lower burden on banks, who would not have faced higher reserve requirements to prevent the higher monetary base feeding through to broad money; and a lower subsequent vulnerability to capital outflows. ${ }^{14}$

Failure to tighten fiscal policy also increased the nature of the one-way bet for speculators by revealing that, if defense of the parity became necessary, it would initially be undertaken by some combination of raising interest rates and selling of foreign exchange reserves. ${ }^{15}$ Speculators might well have time to get out. Given commitments to disinflation, only the willingness to use fiscal policy could have raised ex ante the prospect of serious interest rate reductions and a danger of accompanying exchange rate depreciation that would have inflicted capital losses on speculators in koruny during 1995-96. Indeed, one way to interpret the drying up of capital inflows when the band was first widened in 1996 is precisely that speculators took account of the possibility of accompanying fiscal action. Once this failed to materialize, and it became evident that monetary policy was the only defense, this paradoxically provided a window in which inflows became attractive once more.

Having appreciated to near the edge of the band in the first quarter of 1997, the nature of the one-way bet then reversed. Since an appreciation of the parity was implausible given the $8 \%$ current account deficit, the prospect of further capital gains on the currency was eliminated. Henceforth, only capital losses were possible. Capital inflows abated because perceived deviations from interest parity were no longer favorable; coupled with the large current account deficit, this induced a balance of payments deficit and reserve outflows. In such a vulnerable position, sooner or later an exchange rate crisis was extremely likely.

Tighter fiscal policy might have had one further advantage; it might have achieved a better composition of aggregate demand. Table 5 makes clear that the 1997 slowdown failed to take place in household consumption. Given what we know from monetary transmission in OECD countries, it would have been surprising if monetary tightening in 1996 had worked through that quickly to consumer expenditure. Yet slower consumption growth had to be an integral part of any attempt to retain the parity. Higher taxes would have bitten more quickly on consumption.

\subsection{Did Microeconomic Failures Compound the Problem?}

After initial stabilization, successful transition is mainly about microeconomics; the job of macroeconomics thereafter is not to get in the way. Getting in the

\footnotetext{
14 The true fiscal cost of sterilization is the deviation from interest parity multiplied by the stock of cumulated inflows thereby attracted unnecessarily.

${ }^{15}$ Revision of private sector beliefs about the preferences of government is, of course, capable of triggering a sharp revision in expectations about the future policy regime, a process that falls squarely within the analysis of Obstfeld $(1995,1996)$.
} 
way includes adopting an unhelpful policy mix that creates substantial strains through overvaluation, overheating, or confidence crises about internal or external solvency. In this section, my concern is not whether macroeconomic policy impeded structural adjustment, but whether inadequate structural adjustment made the operation of macroeconomic policy much more difficult. Three areas deserve further examination: fragility of banks, off-balance-sheet fiscal liabilities, and inadequate corporate control. They are of course connected and raise difficult issues faced by all transition economies.

The fragility of banks during transition is by now well understood and perhaps should have been anticipated more than it was; such problems had been prevalent for example in Latin America for the previous two decades. Increasingly, the importance of financial regulation has been recognized in the licensing of banks, financial disclosure, provisioning for bad loans, and capital adequacy requirements. Banks are important for their role in corporate governance and in the transmission of monetary policy. A fragile banking system gives rise to two problems critical in the defense of an exchange rate parity in time of crisis: the standard medicine of squeezing credit may be imperfectly applied, for example because banks fear the consequences either for their clients or for themselves; and, anticipating this, policymakers may be reluctant to administer the medicine in full strength. ${ }^{16}$ Despite these considerations, it is evident that the credit squeeze was eventually administered with considerable severity in the Czech Republic. PRIBOR 3-month interest rates rose from $12.4 \%$ during January through April 1997 to $20 \%$ in May, the month of the crisis, and 26\% in June, before falling back to $17 \%$ in July.

The banking system is also a channel, though not necessarily a cause, of a second way in which microeconomic foundations impinge on macroeconomic policy. Off-balance-sheet liabilities accumulated through the banking system but ultimately a fiscal liability of the government are a classic example of the soft budget constraint. In the Czech Republic, receipts accumulated in the stateowned Privatization Fund were then pledged on occasion as collateral for guarantees to banks of loans to individual enterprises whose demise or contraction the government was anxious to avoid. Where bad debts arose, they were slow to be acknowledged. Although it would be wrong to compare the Czech Republic unfavorably with other transition economies in a similar position, such practices were tantamount to a hidden fiscal expansion unrecorded in national income statistics for annual flows. In this regard, the earlier portrayal in Table 1 of fiscal rectitude by a central government overstates the case. By the same token,

\footnotetext{
${ }^{16}$ Begg (1996) noted that, in addition to sterilization of the monetary base, many countries including the Czech Republic had also pursued sterilization of capital inflows by policies to reduce the money multiplier by raising reserve requirements, essentially a tax on banks. Taxing banks that are already fragile may frustrate progress with structural adjustment.
} 
recognition of reality strengthens the argument that an earlier fiscal tightening would have been desirable.

The third channel through which microeconomics made macropolicy more difficult was the concern that there was insufficient discipline on wage setting, in part because of inadequate corporate governance. Section 4.1 argued that, for several years, wages had been growing substantially in excess of productivity. Clearly, this reflected partly the unwinding of the substantial real wage cut imposed by the 1991 devaluation at the start of the peg. Moreover, it could be argued that $4 \%$ unemployment was insufficient to provide labor market discipline. Since the import surge reflected partly booming consumption, more effective corporate governance and wage discipline might have mitigated this pressure.

\subsection{Should the Peg Have Been Abandoned Earlier?}

Thus far, the dilemma has been viewed through Czech spectacles, discussing alternative policies without the sacrifice of Czech exchange rate policy. Should the exchange rate peg simply have been abandoned earlier? The time to exit smoothly from an exchange rate peg is before the market expects it. Once it looks to be the last resort, it is already too late. Widening the band in February 1996 did, of course, allow a greater degree of exchange rate flexibility than before. The lessons drawn in Sections 4.4 and 4.5 are relevant to the issue of what complete abandoning of the parity would have implied.

Suppose in 1996 a managed float had been adopted. The economy was overheating; disinflation remained a priority; reluctance to countenance fiscal tightening was a political reality. Thus, the central bank would have been driven to tighten monetary policy and the exchange rate would have appreciated, perhaps even more than its actual appreciation within the wide band. The trade deficit would have widened even more quickly. If, by some chance, the floating exchange rate had not appreciated or had even depreciated, domestic overheating would have been that much greater, the eventual monetary medicine that much tougher, and the inappropriate monetary-fiscal mix that much more dramatic.

This thought experiment reveals that fiscal adjustment was necessary whatever the exchange rate regime. Given the political situation, it probably required a crisis to make that adjustment politically feasible. Whether the trigger was a steep depreciation of a floating exchange rate or a run on reserves of a pegged rate may not have mattered. ${ }^{17}$

\footnotetext{
${ }^{17}$ In their empirical examination of speculative attacks in many countries throughout the past three decades, Eichengreen et al. (1996) observed that crises are by no means confined to countries having fixed exchange rates.
} 


\section{HOW HARD A LANDING?}

However traumatic the events culminating in May 1997 were to those in the Czech Republic, to many outside observers there has been a reasonably soft landing since the adoption of the managed float in May 1997. Official foreign exchange reserves, some $\$ 12.4$ billion in the fourth quarter of 1996 , had fallen by $\$ 1$ billion by April 1997 and then even more sharply to $\$ 10$ billion during May. Yet once the crisis was over, and some accompanying fiscal adjustment undertaken, by July reserves had been rebuilt to $\$ 10.8$ billion. At no stage was external assistance requested or required. PRIBOR, which had averaged 12\% in 1996, reached 20\% in May 1997 and 26\% during June, but by July it had fallen back to $20 \%$. There was no banking crisis. By the second quarter of 1997 , for the first time in two years, export growth exceeded import growth.

By July 1997, the real exchange rate index as defined in Table 3 was 129.4, compared with 125.4 in 1995 and 132.6 in 1996. In view of Fig. 1, it is important to restate that the crisis merely restored competitiveness to its levels of the recent past. In part this reflects a subsequent rebound of the nominal exchange rate and in part the pass through of devaluation into wages and prices. If the landing, initially soft, is sustained, it will be because it has forced belated adjustment of other policies, most notably fiscal policy, not because of its direct effects on competitiveness. Hence, it will reflect expenditure reduction not expenditure switching. By the same token, any early easing of policy risks rapid precipitation of another crisis.

Official data for the state budget had recorded a small surplus of $0.5 \%$ of GDP in 1995 followed by a small deficit of $-0.1 \%$ in 1996 . However, these data understate the deficit in the ways mentioned above, most notably by ignoring deficits of local governments and by treating depletion of the Privatization Fund as revenue rather than financing of a deficit. Properly measured, the budget deficit had been $1.8 \%$ in 1995 and 1.2\% in 1996. The crisis of April through May 1997 provoked expenditure cuts totaling $2.5 \%$ of GDP, which should go some way to provide the fiscal tightening suggested above. However, these cuts were not intended to be reflected entirely in the structural budget position, to some extent they were a response to the first-quarter slowdown and consequently lower projections for future tax revenue. The implication of the previous analysis is that further changes in the monetary-fiscal mix may yet be desirable.

Although the peg was abandoned on May 27, policy discussions had been intense since a sharp depreciation within the band on May 15 (see Fig. 2). Because the speculative attack on the Thai baht had taken place only a few days earlier, contagion may have played some role in the timing of the crisis. ${ }^{18}$ However, it is difficult to see the Czech crown as the innocent victim of

${ }^{18}$ The Czech crown and the Thai baht previously had similar risk characteristics and therefore often had tended to be bracketed together by investors in emerging markets (see Czech National Bank, 1998). 


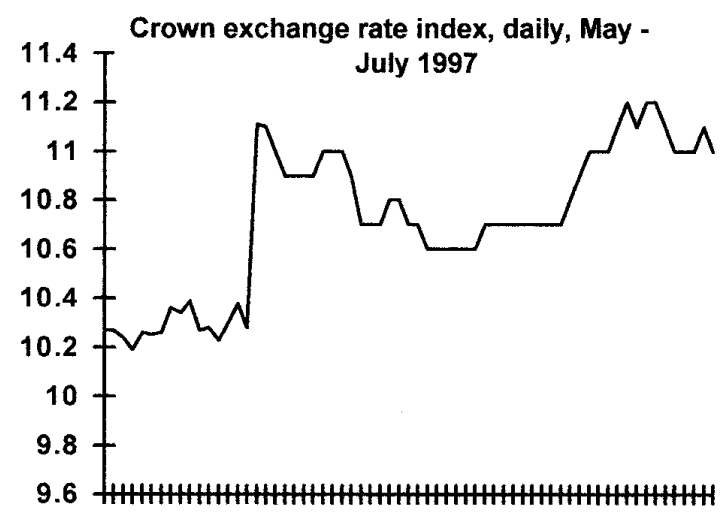

FIG. 2. The crisis of May 1997 and its aftermath. The crisis began in the early hours of May 15 when the Crown fell sharply within the band to 5\% below the central parity. To defend the currency, the central bank engaged in substantial unsterilized intervention, reflected in reserve losses and sharply higher interest rates. Access to Lombard credit was first restricted and then terminated. Only a radical fiscal adjustment might have enabled the original exchange rate to survive in the medium run. With the government unwilling, and perhaps unable, to attempt such a policy, an announcement was made on the evening of 26 May that the band was being abandoned in favor of a managed float, using the DM as a reference currency. In the immediate aftermath of the crisis, Lombard credits remained closed, and interest rates remained high. Interest rate spreads were high, reflecting uncertainty in banking. Within a month, confidence improved, interest rates were eased, Lombard credit reopened, and spreads began to fall. July and August saw further consolidation. By the end of August 1997, real interest rates had returned to almost pre-crisis levels. Horizontal scale: Daily, starting on May 1, 1997. Vertical scale: 10 = exchange rate of the koruna on January 1, 1997. Source: Czech National Bank (1998).

speculative frenzy. The trend deterioration of competitiveness, sustained over several years, was evident. The fact that, once the crisis was over, the real exchange rate has reverted almost to the levels of 1996 suggests that some other change in fundamentals must have taken place. The induced change in fiscal policy must be the prime suspect.

\section{CONCLUSION: MORE GENERAL LESSONS}

Macroeconomic orthodoxy, not least that advocated in Washington, often stresses that lax fiscal policy is the source of many macroeconomic evils (Begg, 1996). But lax relative to what? It is natural, but misguided, to fall into the trap of assuming that a balanced budget is therefore sufficient for the avoidance of such difficulties. The Czech example is a salutary lesson that sometimes only a fiscal surplus will suffice. Therefore, simplistic judgments should be avoided. Nor is it sufficient to diagnose the fiscal policy that is needed; it must also be politically feasible to implement it. Sometimes this becomes known only when urgent action is required; sometimes old assumptions are rendered obsolete by 
changes in domestic politics. The Czech example illustrates again the danger of committing one's monetary hands in an environment where fiscal hands may also be, or may become, tied behind one's back. Promises to hold the exchange rate parity are rarely credible when supporting policies cannot be seen to be capable of being deployed appropriately. Relatively fixed parities, circumstances conducive to both occasional dramatic flows and discontinuous adjustment of asset prices, place severe strains on banks, bank solvency, and bank regulators. Other things equal, these pose greater problems for transition economies than mature economies.

While these observations caution against the adoption of narrow bands, they do not imply that the increasing prevalence of wide bands in such economies is an error, though sometimes even wider bands may not have been wide enough. The Czech example does not prove the failure of the wide band that was belatedly adopted there in 1996. By that date, vulnerability had already been increased by massive inflows. Even then, a change in fiscal policy might have been adequate. Had that been undertaken earlier, it is likely that a less dramatic fiscal adjustment would have been required.

Finally, the Czech example provides no comfort to those who believe in the twin orthodoxies of low inflation and privatization. Displaying these in undue measure for a transition economy elevated the Czech Republic to star status. However, as the seventh anniversary of the big bang policy approaches, cumulative output performance has remained disappointing, progress with structural adjustment has been limited, "Czechbook" privatization has not conferred reliable corporate governance, and the development of a healthy banking system is a task begun but not yet completed. As we have learned more recently from East Asia, the roots of crisis are not always to be found in macroeconomics. However useful it may be to enjoy an apparently stable macroeconomic environment, healthy microeconomics matters too.

Transition economies offer the promise of sounder microeconomics in the future. Where, as in the Czech Republic, the macroeconomic strategy relies on substantial foreign borrowing against the prospect of this future success, maintaining the confidence of lenders is intrinsic to success. Although much of this analysis has examined the evolution of macroeconomic pressures, about which data are so much more readily available, this in no way implies that the microeconomic issues are unimportant.

\section{REFERENCES}

Begg, David, "Monetary Policy in Central and Eastern Europe: Lessons after Half a Decade of Transition.” IMF Working Paper WP/96/108. Washington DC: International Monetary Fund, 1996.

Begg, David, "Disinflation in Central and Eastern Europe: The Experience to Date." In Carlo Cottarelli and Gyorgi Szapary, Eds., Moderate Inflation: The Experience of Central and Eastern Europe Transition Economies, pp. 102-126. Washington, D.C. and Budapest: International Monetary Fund \& National Bank of Hungary, 1998. 
Begg, David, Hesselman, Linda, and Smith, Ron, "Money in Transition: How Much Do We Know?" Mimeo. European 1 Department, Washington, D.C.: International Monetary Fund, 1996.

Calvo, Guillermo., Leiderman, Leo, and Reinhart, Carmen, "Inflows of Capital to Developing Countries in the 1990s: Causes and Effects." J. Econom. Perspectives 10, 2:123-139, Spring, 1996.

Cottarelli, Carlo, and Szapary, Gyorgi, Eds, Moderate Inflation: The Evidence of Central and Eastern Europe Transition Economies. Washington, D.C. and Budapest: International Monetary Fund and National Bank of Hungary, 1998.

Czech National Bank, "Monetary Turbulence of the Czech Crown in May 1997." Mimeo. Prague: Czech National Bank, 1998.

European Bank for Reconstruction and Development (EBRD), Transition Report. London: European Bank for Reconstruction and Development, 1996.

Eichengreen, Barry, Rose, Andrew, and Wyplosz, Charles, "Exchange Market Mayhem: The Antecendents and Aftermath of Speculative Attacks." Econom. Policy, 0, 21:249-296, Oct., 1995.

Eichengreen, Barry, Rose, Andrew, and Wyplosz, Charles, "Contagious Currency Crises." CEPR Discussion Paper 1453. London: Centre for Economic Policy Research, Aug. 1996.

Flood, Robert, and Garber, Peter, "Collapsing Exchange Rate Regimes: Some Linear Examples." J. Internat. Econom. 17, 1-2:1-13, Aug. 1984.

Halpern, Laszlo, and Wyplosz, Charles, "Equilibrium Exchange Rates in Transition Economies." IMF Staff Papers, Vol. 44, No. 4, pp. 430-461. Washington, D.C.: International Monetary Fund, Dec. 1997.

IMF, International Financial Statistics. Washington, D.C.: International Monetary Fund, November, 1997.

Krugman, Paul, “A Model of Balance of Payments Crises.” J. Money Credit \& Banking 11, 3:311-25, Aug. 1979.

Krugman, Paul, and Rotemberg, Julio, "Speculative Attacks on Target Zones.” In Paul Krugman and Marcus Miller, Eds., Exchange Rate Targets and Currency Bands, pp. 117-133. Cambridge, UK: Cambridge University Press, 1992.

Leiderman, Leo, and Bufman, Gil, "Searching For Nominal Anchors in Shock-Prone Economies in the 1990s: Inflation Targets and Nominal Exchange Rate Bands.” In Ricardo Hausmann and Helmut Reisen, Eds., Securing Stability and Growth in Latin America: Policy Issues and Prospects for Shock-Prone Economies, pp. 79-126. Paris: Organisation for Economic Cooperation and Development, 1996.

Obstfeld, Maurice, “The Logic of Currency Crises.” In Barry Eichengreen, Jeffry Frieden, and Jurgen von Hagen, Eds., Monetary and Fiscal Policy in an Integrated Europe, pp. 62-90. Heidelberg, New York and London: Springer-Verlag, 1995.

Obstfeld, Maurice, "Models of Currency Crises With Self-Fulfilling Features." European Econom. Rev. 40, 3-5:1037-1048, April 1996.

Obstfeld, Maurice, and Rogoff, Kenneth, Foundations of International Macroeconomics. Cambridge, MA and London, MIT Press, 1996.

OECD, Economic Outlook. Paris: Organisation for Economic Co-operation and Development, June 1997.

Portes, Richard, and Vines, David, "Coping with Capital Inflows.” Economics Paper 30. London: UK Commonwealth Secretariat, 1997.

Pujol, Thierry, and Griffiths, Mark, "Moderate Inflation in Poland: A Real Story." IMF Working Paper, WP/96/57, Washington, D.C.: International Monetary Fund, 1996.

Sachs, Jeffrey, "Economic Transition and the Exchange-Rate Regime." Amer. Econom. Rev. Papers Proc. 86, 2:147-152, May 1996.

Sachs, Jeffrey, Tornell, Aaron, and Velasco, Andres, "The Collapse of the Mexican Peso: What Have We Learned?" Economic Policy 0, 22:13-56, April 1996.

Velasco, Andres, "Fixed Exchange Rates: Credibility, Flexibility, and Multiplicity." European Econom. Rev. 40, 3-5:1023-1035, April 1996. 